1990

\title{
What Do We Mean by Law and Social Transformation?
}

Judy Fudge

Osgoode Hall Law School of York University

\section{Source Publication:}

Canadian Journal of Law and Society/Revue Canadienne Droit et Société. Volume 5 (1990), p. 47-70.

Follow this and additional works at: https://digitalcommons.osgoode.yorku.ca/scholarly_works (c) (1) $(9)$

This work is licensed under a Creative Commons Attribution-Noncommercial-No Derivative Works 4.0 License.

\section{Recommended Citation}

Fudge, Judy. "What Do We Mean by Law and Social Tranformation?" Canadian Journal of Law and Society 5 (1990): 47-70.

This Article is brought to you for free and open access by the Faculty Scholarship at Osgoode Digital Commons. It has been accepted for inclusion in Articles \& Book Chapters by an authorized administrator of Osgoode Digital Commons. 


\title{
What Do We Mean by Law and Social Transformation?*
}

\author{
Judy Fudge \\ Osgoode Hall Law School \\ York University
}

\begin{abstract}
In Canada the entrenchment of the Charter of Rights and Freedoms generated a good deal of debate about the possibility of using law in the struggle for social transformation. Although couched in general terms, the current debate is ultimately about the possibility of asserting liberal democratic legal rights in courts in order to transform existing relations of subordination and domination. Somewhat remarkably, the positive claim that litigating entrenched legal rights encourages social transformation tends to be made almost exclusively at the theoretical level. Theoretical possibilities, rather than concrete victories, are invoked to support the claim for the transformative capacity of liberal legal rights. Instead of approaching the question of litigating social change from an exclusively theoretical perspective, this paper examines contemporary examples in order to illustrate some of the possibilities of and limits to this strategy. Specifically, the paper examines how both the labour and women's movements have used the Canadian Charter of Rights and Freedoms to further their social, political and economic goals. Not only did these two groups adopt widely different strategies during the entrenchment process, what is entailed by the assertion of bourgeois legal rights has a different meaning for each. Thus, by contrasting the experience of the labour and women's movements in invoking the Charter it is possible to begin to suggest the limits of liberal rights in the struggle for social transformation.
\end{abstract}

Résumé - Au Canada, la défense de la Charte des droits et des libertés a donné lieu à une quantité de débats sur l'utilisation possible de la Loi pour obtenir des changements sociaux. Présenté d'une façon très générale, le débat actuel propose en fait la possibilité de revendiquer des droits légaux, libéraux et démocratiques devant les tribunaux pour transformer les situations de domination et de subordination qui existent maintenant. Il semblerait que, d'un point de vue théorique, la lutte pour la défense des droits a la justice encourage le changement social. Des possibilités théoriques, plutôt que des victoires concrètes, sont invoquées pour 
supporter la thèse de la capacité transformative des droits légaux et libéraux. Au lieu d'une approche théorique au sujet du litige pour obtenir des changements sociaux, cette étude examine plutôt des exemples contemporains pour illustrer les possibilités et les limites de cette méthode. Plus particulièrement, cette étude analyse comment le mouvement ouvrier et le mouvement féministe se sont servis de la Charte Canadienne des droits et des libertés pour atteindre leurs objectifs sociaux, politiques et économiques. Non seulement ces deux groupes ont-ils adoptés des stratégies différentes pendant le procédé de retranchement, mais ce qui est requis pour la revendication de droits légaux bourgeois a une signification différente pour chacun d'eux. Donc, en établissant le contraste entre l'expérience du mouvement ouvrier et celle du mouvement féministe vis-d̀-vis de la Charte, on peut ébaucher les limites des droits sociaux dans la lutte pour la transformation sociale.

Historical consciousness ought to assist one to understand the possibilities of transformation and the possibilities within people. E.P. Thompson

What are the limits to and the possibilities of using law in the struggle for social transformation? This question has triggered a lively debate. In Canada it was sparked by the introduction of the Charter of Rights and Freedoms ${ }^{1}$ and in Britain by the authoritarian populism of Thatcher's conservative government and her attack on traditional civil liberties. Governments in Westem Europe and North America have, to varying degrees, responded to the series of shocks to the Keynesian economic and social compromise which occurred during the 1970 s by realigning the institutional balance further in favour of capital. Wage controls were implemented, deregulation and privatization characterized economic policy, and inflation and deficit reduction triumphed over unemployment and social welfare on the political agenda. Social democractic and other labour-aligned political parties seem either incapable of or unconcerned with stopping the spread of the new conservative economic and political wisdom. Consequently, since the beginning of the 1980s the (broadly-defined) left increasingly has come to doubt that legislative politics will lead to social transformation. Moreover, the fact that authoritarian populist governments have started to erode what had previously seemed secure civil liberties, reinforces the left's disillusionment with electoral politics and nourishes the search for an alternative arena of struggle. ${ }^{2}$ It is in this context which we must place the call for the defence and expansion of liberal legal rights. ${ }^{3}$

Two articles recently published in Canada come down on the affirmative side of the debate on the transformative capacity of law-according to Brickey and Comack, and Bartholemew and Boyd, law can be used in the struggle for progressive social transformation. ${ }^{4}$ Both pieces offer impressive syntheses of a growing 
literature which attempts to locate law in the wider social relations of domination and subordination. Moreover, each rejects a dichotomized approach to theory and a unidimensional conception of law. According to Brickey and Comack "law offers an important (although by no means the sole) source for realizing substantive social change." 5 Drawing upon their survey of the Canadian political economy approach to law, Bartholemew and Boyd conclude that "[1]aw, legal institutions, and rights represent both spaces and tensions, contradictions and possibilities, limitations and potential." 6 And both sets of authors assert that the way forward is to develop a theory of law which incorporates and recognizes law's transformative potential. ${ }^{7}$

Although it is couched in general terms, the current debate is ultimately about the limitations and possibilities of liberal democratic legal rights for transforming existing social relations of domination and subordination. The struggles for liberal legal rights by the women's and civil rights movements have been cited as evidence for the conclusion that the struggle for liberal legal democratic rights is an important part of the overall struggle for social transformation. 8 Sumner makes the strong claim that a socialist transformation requires the extension of liberal legal (or civil) rights to all members of the working class:

the formation of the class-for-itself has necessary legal conditions (de jure and de facto), e.g., legal personality for all (i.e., including prisoners, bastards, lunatics, women, immigrants-all at one time or one place effectively split off from the rest of the class by legal procedures and institutions, universal sufferage, the right to free association), the right to own property, the right of disposal of one's own body, etc. I would suggest that some substantial experience of winning and enjoying these freedoms is a necessary precondition of the formation of a class culture with a full sense of socialist democracy. ${ }^{9}$

Sumner's claim is significant because he is arguing that the expansion of bourgeois legal rights is a necessary condition for social transformation. The legislative arena has always been viewed as an important, although insufficient, arena of engagement precisely because it is clearly identified as part of the political arena. The pre-eminent juridical forms and institutions-bourgeois legal rights and the common law courts-are now conceived of as important elements of the struggle for transformation. This is what is new about Brickey and Comack's and Bartholemew and Boyd's analyses-they are urging us to take the extension of liberal democratic legal rights in the judicial forum seriously. Sumner, however, acknowledges that the realization of civil liberties and a rule of law which protects people from the coercive aspects of both public and private authority depends on the overthrow of capitalist economic relations and the establishment of socialism, since "[c]apitalism must always betray its legal promises." 10 Thus, the question ultimately is whether the assertion of bourgeois rights in the courts allows us to challenge, or whether it merely reinforces, capitalist social relations. In contrast to Sumner, neither Bartholemew and Boyd, nor Comack and 
Brickey specify what they mean when they claim that law is essential for social transformation. For them it is sufficient that subordinate groups have sought recourse to the judicial forum to articulate their demands in the form of the extension of liberal democratic rights. 11 But, as Ellen Wood has noted,

it is precisely the recourse that subordinate groups have had to judicial and political institutions in their relations with the dominant classes, together with restrictions on the 'freedom' of the state itself, that have created a faith-though hardly unlimited-in the efficacy of legal and political forms. 12

Faith alone is not enough to support a strategy. Rather, we need to examine concrete examples in order to discover what limits are imposed upon, and what possibilities are created by, the capitalist regime, its material order and its configuration of social power upon the transformative capacities of liberal legal rights.

In what follows I shall examine two examples involving attempts by differently situated groups, the labour movement and the women's movement, to invoke the Canadian Charter of Rights and Freedoms to extend bourgeois legal rights to their benefit. It is interesting to note the different positions of the two groups. They adopted widely different strategies during the entrenchment process; the labour movement abstained from participating whereas the women's movement used that process as an occasion for mobilizing. Moreover, what is entailed by the extension of bourgeois legal rights has a different meaning for each group. Trade unions have sought to expand their freedom to strike and to picket to influence industrial disputes in the face of legislative and judicial limitation by invoking the Charter's protection of the right to free expression and the right to associate. Essentially, trade unions have attempted to extend the traditional bourgeois rights to collective entities for the purpose of economic action. The women's movement, on the other hand, has sought to extend bourgeois legal rights such as equality and natural justice to include a substantive, and not merely formal, component. By contrasting the experience of these two groups it may be possible to begin to suggest the limits of liberal rights in the struggle for social transformation.

\section{Trade Unions and Liberal Rights}

Since the 1980 s both provincial and federal governments in Canada have, to various degrees, undermined the post-war legislative framework regulating labour relations. The imposition of wage and price controls, ad hoc back to work legislation, the revocation of thousands of workers' right to engage in lawful strikes, and provincial legislation rolling back hard won collective bargaining entitlements have led Panitch and Swartz to claim that the 1980s ushered in a change in the labour relations paradigm from consent to coercion. ${ }^{13}$ 
In the face of these assaults unions have come to regard the avowed legislative commitment to "free" collective bargaining with skepticism. Thus, some unions have sought to invoke the Charter of Rights and Freedoms to defend their traditional collective bargaining entitlements from legislative incursions which seek to limit workers' freedom to strike. Other trade unions have tried to extend their collective power by using the Charter positively. They have challenged the legal rules limiting the scope of lawful picketing on the basis that such limitations constitute an infringment of their freedom of expression. To date the Supreme Court of Canada has issued six Charter decisions ruling upon trade union challenges to restrictions on the use of their collective power. ${ }^{14}$ Despite carefully crafted legal arguments and sporadic academic protest, organized labour has lost each time it has appeared before the Supreme Court to invoke the Charter in order either to extend or protect its collective power.

Panitch and Swartz attribute labour's lack of success under the Charter to its failure to participate in the constitutional debate which took place in the early 1980s. They charge that organized labour failed to present any challenge to the liberal individualist philosophy that the Charter espouses. 15 However, the important question is not whether organized labour was at fault for failing to enter into the constitutional debate, but whether labour's intervention would have made a significant difference to the philosophy embedded in the Charter. Even Panitch and Swartz acknowledge that this is unlikely. Recent work placing the Charter in its political context suggests that it was designed to provide a mechanism to co-opt Quebec's struggles around language and independence, rather than to provide greater freedom for the majority of Canadians. 16

If one turns to the cases decided by the Supreme Court which deal with labour's collective rights under the Charter, it is clear that they reinforce and extol legal relations, principles and categories essential to capitalist production relations. In the trilogy of right to strike cases, a plurality of the Supreme Court issued a one-page decision which held that the "the constitutional guarantee of freedom of association found in s. 2(d) of the Canadian Charter of Rights and Freedoms does not include, in the case of a trade union, a guarantee of the right to bargain collectively and the right to strike. ..."17 Starting from the premise that freedom of association only includes those objects of association in which other fundamental rights are implicated, Le Dain proceeded to characterize the "modern" rights to bargain collectively and to strike as "the creation of legislation," rather than fundamental rights. Hence, he held that the rights to bargain collectively and to strike are not protected by the Charter. And in his concurring judgement, MacIntyre interpreted "freedom of association to mean that every individual is free to do with others that which he is lawfully entitled to do alone." 18 Striking, according to MacIntyre, is a collective right and, thus, is qualitatively different from an individual right. Consequently, he decided that the right to strike is not protected by the freedom to associate.

The right to strike trilogy provides a strong signal to governments across 
Canada that they are free to roll back workers' traditional legislative freedoms to bargain collectively and to strike. Individual rights as opposed to collective rights are to be protected. Fundamental rights and freedoms inhere in the common law, and not modern legislative enactments. This bodes ill for labour, since workers have often exercised their democratic rights to obtain legislation which modifies the worst aspects of the common law regime.

But of even greater significance than the trilogy of strike cases for demonstrating the limits of Charter litigation to further workers' struggles is the Supreme Court's decision in R.W.D.S.U. v. Dolphin Delivery. 19 Although the case raised the issue of whether or not an injunction founded on the basis of the common law torts and issued to prevent peaceful secondary picketing constituted a violation of the union's freedom of expression, it was decided on the basis of the scope of the Charter's application. According to MacIntyre, writing on behalf of a unanimous court, the issue was whether the Charter applies to private litigation which was enforced via a court-issued injunction. While admitting that from a political science standpoint the courts are unquestionably one of the three fundamental branches of government (legislative, executive and judicial), he concluded that to "regard a court order as an element of governmental intervention necessary to invoke the Charter would, it seems to me, widen the scope of Charter's application to virtually all private litigation." 20 Thus, the union's Charter argument failed, as the Court held that the Charter does not apply to an injunction granted by a trial judge applying the common law tort doctrine of inducement of breach of contract.

In Dolphin Delivery, the Supreme Court demonstrated that it is not prepared to interpret the Charter so as to authorize judicial intervention into the private sphere, even though the allocation of private rights is underwritten by state power. Evidently, the Court's fear is that, if the Charter applies to a court order, such as an injunction, an entire range of "private" dealings based on legal relations such as contract and property, would be subject to review on the basis of an alleged infringement of fundamental rights and freedoms. According to the Supreme Court, the constitutionally entrenched rights guaranteed by the Charter protect the individual from the state, rather than protecting a weaker individual from a more powerful one, even if the second individual's power is dependent upon court enforcement of a web of legal relations.

The final two cases handed down by the Supreme Court of Canada dealt with the issue of whether the Charter protects peaceful picketing by public sector workers in front of provincial courts during lawful strikes.21 During the course of a lawful strike, the British Columbia Government Employees Union (the Union) posted pickets at the entrance to the courts of the province. The Union issued passes to authorize people, including officers of the court, to pass through the picket lines. When he arrived at the courthouse that morning, the Chief Justice of the Supreme Court of British Columbia (McEachern) issued, on his own motion and ex parte, an injunction prohibiting the picketing of any courts 
in the province. McEachern later dismissed the Union's application to have the injunction set aside, and his decision was upheld by a unanimous Court of Appeal.

At the Supreme Court Dickson characterized the case as involving "the fundamental right of every Canadian citizen to have unimpeded access to courts and the authority of the courts to protect and defend that constitutional right."22 The Union argued that the injunction violated, among other things, its right to engage in peaceful picketing which was guaranteed under the Charter's protection of the freedom of expression. Invoking the rule of law, which he regarded as fundamental to the Charter, Dickson posed the following thetorical question:

How can the courts independently maintain the rule of law and effectively discharge the duties imposed by the Charter if court access is hindered, impeded or denied? The Charter protections would become merely illusory, the entire Charter undermined.23

After finding both that the Charter applied to the injunction and that peaceful picketing during a lawful strike was prima facie protected activity under the Charter's guarantee of freedom of expression, the Court went on to hold that McEachern's injunction was a justifiable limitation. According to Dickson:
A balance must be sought to be attained between the individual values and the public or societal values. In the instant case, the task of striking a balance is not difficult because without the public right to have absolute, free and unrestricted ac- cess to the courts the individual and private right to the freedom of expression would be lost. The greater public interest must be considered when determining the degree of protection to be accorded to individual interests. 24

The importance of this decision lies in its invocation of a purely formal and eviscerated juridical conception of the rule of law as the foundation for the enjoyment of the rights and freedoms contained in the Charter, its characterization of picketing as an individual right in contrast to the public right of formal access to justice, and the total absence of any acknowledgement of the history of the courts' use of equitable remedies such as injunctions to maintain the subordination of workers. Moreover, despite the fact that in a very similar situation in Newfoundland where picketing had gone on for several days without causing any "massive disruption" to the administration of justice, the Supreme Court took judicial notice of the havoc court house picketing would wreak upon the rights of Canadians.

In each of these cases the Supreme Court has decided not to use the Charter to defend workers' "right" to strike or extend their freedom to picket. This suggests that Charter litigation will prove to be a particularily unfavourable arena in which to engage with the law for the purposes of transforming unequal power relations between workers and employers which are upheld and partially constituted 
by the common law. Not only are there structural and institutional limitations to the types of decisions that the courts can make on a systematic basis, the nature of abstract rights and freedoms makes the Charter a tool of the powerful, as well as the powerless. In fact, institutional limitations which undermine real access to justice (the availability of legal resources), the socialization of the judiciary, the form of legal argumentation, as well as the structural constraints imposed by essential legal relations, distinctions and principles, render the courts perhaps the least suitable of the existing legal fora for engaging in struggles for social transformation. 25 Other legal institutions may prove to be more permeable to transformative arguments. To date it has been through struggles in the workplace, on the streets and in the legislative arena, whatever the latter's failings, that workers have obtained some relief from exploitive employment relations - as the examples of the factory acts, 26 workers compensation acts 27 and collective bargaining legislation 28 attest. Moreover, workers have made these gains despite the initial willingness of the courts to strike them down.29 And it is precisely these gains that the Charter renders subject to legal challenge. 30

\section{Feminist Struggles}

Simply because the labour movement has been unable to extend bourgeois legal rights does not necessarily mean that other groups, in particular the women's movement, cannot use these rights to transform aspects of social relations which oppress women. It is possible that the labour movement's aspirations are peculiarily incompatible with the extension of bourgeois rights. Collective rights addressed to economic inequality would challenge legal relations which are essential to capitalism. But not all forms of oppression are, however, so closely tied to class relations. Women's sexual and economic subordination to men, although linked with, is not directly reducible to, class relations. ${ }^{31}$ Consequently, it is possible that the extension of legal rights may help to transform women's sexual and economic subordination to men.

There are two aspects to this claim. The first is that the demand for formal legal equality itself may be an important progressive demand for feminists. According to Eisenstein:

[a]ll feminisms contain aspects of liberal feminism at their core-the demand for equality, freedom of individual choice, and the recognition of woman as an autonomous being. However feminism chooses to define these particular demands these are its starting points. 32

The second aspect of the claim for the progressive role of bourgeois legal rights is that the assertion of constitutional and other general legal rights is an extremely important and positive political act for feminist organizations. Bourgeois legal rights are conceived of as important catalysts around which to 
mobilize political action. While these two claims are interconnected, I will deal with each separately in order to illustrate what I think are the limits to a strategy which involves the judicial expansion of bourgeois legal rights as part of the struggle for social transformation.

Nowhere has the argument for the significance of legal rights and formal equality as the first step in the feminist struggle for substantive equality been made more persuasively than with respect to the issue of reproductive freedom for women. The demand for access to safe, legal and funded abortion has been a cornerstone of the struggle for full sexual and reproductive freedom, which is, in turn, "an essential precondition to full and equal participation in society."33 According to Gavigan, concepts such as freedom, equality, autonomy and privacy, which are central to liberal law, may in fact be used to legitimize women's right to demand control of their bodies and to reject state interference. This is particularly true in countries such as Canada where the criminal law has been used to control or regulate women's reproductive capacity. Until January 28, 1988 when the Supreme Court of Canada handed down its decision in Morgentaler, 34 the availability of legal abortions was governed by the Criminal Code 35 and determined in practice by hospital administrators and doctors.

The Morgentaler decision was the culmination of two decades of struggle by feminists against the therapeutic abortion provisions of the Criminal Code. ${ }^{36}$ In Toronto feminist and pro-choice activists sought and received the support of Henry Morgentaler and two other doctors to open a free-standing abortion clinic. Thus "[a] public campaign was launched, and the challenge to the federal law was explicit and direct." 37 The clinic was raided and charges were laid. Although Dr. Morgentaler and his two colleagues, Drs. Smoling and Scott, were acquitted by the jury, the Ontario Court of Appeal set aside the verdict and ordered a new trial. Morgentaler, Smoling and Scott appealed to the Supreme Court of Canada on the grounds that the therapeutic abortion provisions contained in the Criminal Code violated the Charter. The Supreme Court of Canada struck down the Criminal Code provision regulating abortion on the grounds that it violated the principles of fundamental justice guaranteed by the Charter.

But once the heady days following the decision had passed, feminists began to look more carefully at the actual basis of the decision in order to prepare for the struggle which lay ahead.38 Although undeniably a victory in that the extremely coercive and arbitrary Criminal Code provision was no longer in effect, a reading of the actual decision demonstrates how narrow the victory actually is.

Amongst the confusing plurality of opinions offered by the Supreme Court regarding the unconstitutionality of the Criminal Code provisions regulating a 'Noman's access to abortion two common themes emerge. First, there was unanimity that the state has an interest in protecting the foetus. Although there was no agreement as to when the state's interest ought to surpass a woman's right to ::ecurity of the person, all of the judges who held that the legislation violated the Charter concurred that the public interest ought, in certain unidentified 
circumstances, to supersede a woman's private right. This left the legal door open for the federal government to attempt to recriminalize abortion. Second, none of the members of the Court addressed the issue of whether or not the government was under an obligation to provide access to safe legal abortions. All they did was declare that the present criminal law regime violated the Charter.

Thus, by striking down the existing legislation, the Supreme Court disclosed the limitations inherent in Charter litigation as an instrument for furthering feminist struggles. Initially, a legal vacuum replaced the criminal provisions; however access to safe and funded abortions continued to depend upon either the response of individual provincial legislatures or individual hospitals. Provincial responses have ranged from an attempt to prohibit public funding of abortions except for those cases involving a serious threat to a woman's physical health or life, to a commitment to fund even those abortions performed in free-standing clinics. ${ }^{39}$ More recently, the federal Minister of Justice has introduced legislation which once again threatens to criminalize abortion. 40 Thus, while the Supreme Court's decision in Morgentaler served in the short run to decriminalize abortion, it has not prevented further attempts by the federal government to recriminalize it nor has it imposed a positive duty upon the state to provide access to safe, funded abortions.

This analysis of Morgentaler suggests not only that it is impossible to divorce legal struggles from broader political struggles, but that legal victories are dependent upon the outcomes of political battles. Morgentaler was itself the outcome of two decades of feminist organizing around the issue of reproductive freedom. The pro-choice position commanded a great deal of public support, as is evidenced by the fact that every jury which tried Dr. Morgentaler for violating the therapeutic abortion provisions in the Criminal Code refused to convict him. Finally the Supreme Court of Canada struck down legislation which was patently unpopular with the majority of Canadian people.

The decision has not, however, ended the debate over the criminalization of abortion, the issue of foetal rights or the question of state funding. A favourable resolution of these issues depends upon the ability of feminists to mobilize in the political arena to obtain legislation which facilitates, rather than restricts, a woman's reproductive choice. Even now a woman's access to safe and funded abortion depends upon extra-legal factors-specifically, the political commitments of the provincial governments and the relative political strengths of the pro-choice and the right-to-life movements. Ultimately, the recognition and enjoyment of bourgeois legal rights depends upon political factors. And even if a new law is crafted which coheres with Morgentaler the struggle is not over. Americans have learnt that judicial decisions are no less subject to reversal than are legislative policies, ${ }^{41}$ and that a change in the political climate which might occasion an alteration in the political composition of the courts can result in the reversal of historic decisions.

Despite the courts' distinctive institutional form and rhetoric, judicial 
institutions make political decisions--decisions which are directly related to the distribution of power and the maintenance of, or encroachment upon, existing social relations. While courts and legislatures are both part of the state, they have different institutional dynamics, roles and principles of legitimation. In fact, one of the limitations of the judicial forum as an arena of progressive strugo,le, as the Morgentaler decision so clearly illustrates, is that the courts are much nore inclined to strike down legislation than they are to fashion a remedy which equires elected officials to make an allocation of resources in order to render the Tharter an effective protection of legal rights. ${ }^{42}$ Ultimately, disadvantaged ,roups, including women, require positive action by the state to redistribute reources in order to address the substantive inequality which they confront in the irivate sphere. 43 Ironically, as we shall see, the liberal rights guaranteed by the Tharter provide another reason for other agencies of the state (the legislature, excutive and administrators) not to do anything which will interfere with private ictivity.

The second aspect of the claim that the assertion of bourgeois legal rights is an mportant part of a progressive strategy for social transformation is that such ights function as catalysts for political mobilization. In Canada, the constituional entrenchment of equality rights became a symbol of profound political ignificance around which many disparate feminist organizations and women's ;roups were able to coalesce. But is this fact alone sufficient support for the :laim that the assertion of bourgeois legal rights in the courts is a transformative truggle? How are we to evaluate the impact of the Charter's guarantee of equali$y$ rights on the mobilization of the women's movement in Canada. Does the act that a wide variety of feminist organizations and women's groups coalesced uround the struggle for constitutionally guaranteed equality rights imply that iuch rights are per se progressive? Or does the fact that such rights functioned as mportant symbols for political mobilization suggest instead something about he abstract and under-determined nature of the demand for general legal rights?

Elsewhere I have attempted to evaluate the claim that the assertion of constituional and other general legal rights is in itself an extremely important and posiive political act. 44 What I found was that while the entrenchment process had a nobilizing and radicalizing influence on the women's movement, various antieminist groups have also employed the Charter as a political symbol, only they ssed it to mobilize opposition to affirmative action for women, to win fathers a iay in abortion, to protect the rights of the foetus, and to secure more rights for nen accused of sexual assault. The fact that the same declaration of abstract and jeneral legal rights was a mobilizing symbol for groups with opposing political igendas is not surprising given the indeterminacy of such rights. According to Hobsbawm, "rights in the sense of wide-ranging claims to a good or a tolerable ife, are not ends in themselves, but broad aspirations which can be realized only hrough complex and changing social strategies, on which they throw no specific light." 45 Abstract legal rights require concrete expression as social policies. 
However, what substantive equality rights for women entails only emerges in the context of particularized litigation.

Thus, it is not possible to evaluate the impact of the entrenchment of equality rights in the Charter solely in terms of the mobilizing effect it has played. Any such evaluation requires specific consideration of the mobilizing effects on different groups. There are, however, other criteria which can be used to evaluate the impact of the Charter. The ultimate goal of the feminist struggle was to provide institutional recognition of women's equality claims and to provide women with a legal remedy if their equality claims were not respected. It is obvious, however, that the actual enjoyment of equality rights is clearly not part of a selfimplementing process. As a result of the government's failure to use proactive means to remedy legislation which has contributed to systemic discrimination against women, feminist lawyers and activists turned to the courts to obtain substantive equality for women.

It is, however, important to evaluate the impact of asserting general and abstract legal rights in the judicial forum not only in terms of its potential mobilizing effect and the actual results of litigation, but also with reference to the form of political discourse constitutional litigation generates. 46 Constitutional litigation is a peculiarly abstract form of political discourse because it requires the assertion of bourgeois legal rights to be uncoupled from a class analysis. Moreover, I want to suggest that this form of political discourse is not confined to the courts, but has imperialistic tendencies which both enables and requires it to invade other political institutions. 47 Only when the hegemonic capacity of abstract legal discourse is recognized is it possible to evaluate whether the entrenchment of abstract and general legal rights will facilitate or impede the struggle to transform oppressive social and legal relations.

The use of the Charter by male defendants to challenge the Criminal Code provisions which are designed to protect women and children from sexual violence or victimization provides an illuminating case study of the impact of the assertion of bourgeois legal rights upon political discourse. 48 Some of the first equality cases argued before the courts were brought by male defendants to invoke the guarantees of sex equality contained in the Charter. They sought to invalidate provisions in the Criminal Code which were designed to protect young women from sexual victimization by older men. In addition, male defendants, among others, have challenged aspects of the legislation which was designed to protect women from the worst abuses of the criminal process relating to the prosecution of sexual offences. 49 Consequently, feminist organizations are having to spend precious time, energy and money in the courts defending legislation that it took women many years to achieve. Perhaps this is the ultimate paradox of the Charter: while feminist organizations are attempting to develop situated and contextual theories of equality which will address women's social and historical subordination, innumerable other litigants, including defendants charged with sexual assault offences and right-to-life organizations, are 
simultaneously invoking the Charter to claim a formal equality which may well erode victories feminists believed they had already won. And this is precisely the effect of uncoupling bourgeois legal rights from social relations of domination and subordination.

Feminists have been heartened by a recent decision of the Supreme Court of Canada which appears to preclude the use of the equality rights guaranteed by the Charter to strike down legislation, including the Criminal Code sexual assault offenses, designed specifically to protect or benefit women. In Andrews v. Law Society of British Columbia,50 the Supreme Court of Canada stated that the equality rights guaranteed by $\mathrm{s}$. 15 of the Charter should not be read formalistically so as to protect only "similarly-situated" groups, but rather should be given a remedial interpretation so as to protect those groups which have historically suffered disadvantage. This interpretation would appear to eliminate claims to equality brought by male defendants accused of sexual assault. However, this decision has come too late for those arguing for the sexual specificity of sexual offences, since the last vestiges of sexual specificity were expunged in response to the first round of successful Charter challenges. 51

Feminists have also argued that a substantive interpretation of the equality rights provision could be used to justify legislation such as the "rape shield" provisions, which would otherwise infringe constitutional protections. Since by far the majority of victims of sexual assault are women, it is possible to argue that rape shield legislation is necessary if women are to participate in society on an equal basis with men. Because the law does not protect the privacy of sexual assault victims, women do not complain to the police and sexual offenders are not prosecuted or punished, with the result that women are intimidated from participating in public life. According to this analysis, women's equality rights under the Charter should trump male defendants' rights to natural justice and a fair trial.52 Of course, it would be up to the judiciary to weigh these competing constitutional rights.

But there is something very peculiar about this argument. Instead of directly confronting the issue of how best to balance the competing social interests and policies, as the federal government did during the 1983 amendments to the sexual assault provisions of the Criminal Code, the argument is cast in the form of competing constitutional rights. In effect, when a defendant raises the issue that the impugned provision violates his constitutional rights he is asking the court to substitute its judgment for that of the legislature. Ignoring for the moment the actual outcome of the court's decision, it is important to attend to the form of the argument. It is essentially dishonest. What the Charter does is detach form from substance. 53 Instead of directly addressing the question of how best to promote women's sexual autonomy under social relations which result in women's sexual subordination, feminists who invoke the Charter must couch their arguments in the rhetoric of equality rights. While it is true that social conditions will figure in their argument, they will figure only indirectly and to the extent 
that it is necessary to establish the rights claim. What the feminist advocate must demonstrate is how the law operates to the detriment of historically disadvantaged groups. 54 Unequal social relations which are not directly sanctioned by govemmental action escape Charter scrutiny, despite the fact that these "private" disparities of wealth and power are the cause of social inequality. In this way the feminist discourse about power and unequal social relations is translated into a discourse of rights and governmental action. Moreover, the legislature need no longer provide a respite from the abstraction and detachment of the courts, for inconvenient discussions of competing social analyses, visions and interests can now be swept away by invoking the Charter. ${ }^{55}$

But the effect of the Charter on the political debate about sexual assault extends beyond its detachment and dishonesty. By reconstituting the political discourse in terms of legal rights, the Charter has polarized and narrowed the debate without challenging prevailing practices. The focus is on how the state ought to respond to coercive sexual practices and the sexual victimization of women and children. Although this emphasis predates the entrenchment of the Charter, the Charter reinforces it since its scope is limited to government action, thereby hardening the ideological separation between the "public" political sphere and the "private" economic and social spheres of life. 56 And even though the equality rights guarantees of the Charter are available for use when incidents of discrimination are alleged by people who can show that they are victims of systemic discrimination because the world of private ordering has made them so, their equality claim only arises where a governmental law perpetuates this. 57

\section{Conclusions}

The above examples are offered not as a proof that bourgeois legal rights are inimical to the struggle for social transformation, but rather as illustrations of the limitations of using bourgeois legal rights to further that struggle. Obviously, this is a very narrow sampling of the limits to asserting bourgeois legal rights as part of the struggle for social transformation but examples in other fields have been offered elsewhere. 58 It may be possible that the attainment of bourgeois legal rights, such as racial equality in the United States, may both contribute to, and be necessary for, the transformation of oppressive social relations. In fact, this claim has been made by a number of authors who insist upon the political significance of the assertion of bourgeois legal rights for visible minorities in the United States. 59 They point to the significance of civil rights litigation as a tactic in the political struggle to end racial subordination in the United States. Historically, racially segregated schooling has epitomized the symbolic and material subordination of Blacks in America.60 After several decades of political mobilization and struggle by Blacks against racial segregation, the Supreme Court of the United States issued Brown v. Board of Education,61 which put an end to the invidious "separate but equal" doctrine which was used to justify 
segregation in legal terms. According to Crenshaw, the

[r]emoval of these public manifestations of subordination was a significant gain for all Blacks, although some benefited more than others. ... These legal reforms and the formal extension of 'citizenship' were large achievements precisely because much of what characterized Black oppression was symbolic and formal. 62

However, despite this legal transformation there has been little positive change in the material conditions of Blacks in the United States. 63 In fact, as recently as the early 1980s a federal district court judge was examining Topeka's schools to determine if they were in compliance with the original 1955 order issued in Brown. 64

Herein lies the rub with a civil rights litigation strategy: while rights rhetoric was employed by Blacks to mobilize state power to their benefit against symbolic oppression through formal inequality, the race neutrality of the legal system simultaneously creates the illusion that racism is no longer the primary factor responsible for the conditions of the Black underclass. 65 In so doing, it has paved the way for the political backlash which has insisted on strict racial neutrality at the expense of affirmative action programmes for Blacks. In fact, the shibboleth of formal equality has been employed by the Reagan administration in the courts to roll back earlier civil rights litigation victories. 66 Now civil rights organizations are once again lobbying Congress to enact legislation which confronts the economic and class conflicts underpinning race relations in the United States. ${ }^{67}$ But the problem is that if race is not connected to class, equal opportunity and merit, and not pervasive social relations, are identified as the cause of disparities of education, income, wealth and power.

The attainment of bourgeois legal rights, however partial and incomplete, by women, visible minorities and native peoples, may be an important symbolic legal victory. However, in order to achieve these symbolic legal victories it is necessary to detach the struggle for bourgeois legal rights from the struggle for social transformation. According to Wood, the strategic implication of this is

that struggles conceived in purely extra-economic terms-as purely against racism or gender oppression, for example - are not in themselves fatally dangerous to capitalism in that they could succeed without dismantling the capitalist system, but at the same time, they are probably unlikely to succeed if they remain detached from an anti-capitalist struggle. 68

Racism and sexism may not be essential for capitalism to survive, but they are so deeply linked in particular histories it may be impossible to end these oppressions without also transforming the vast inequalities of power which are part and parcel of capitalism. But we also know that the transition to socialism will not guarantee the end of racial and sexual oppression. And it is the belief that true democracy in socialism requires real freedoms of expression and association and 
substantive equality upon which our commitment to bourgeois legal rights rests.

The problem is finding a strategy which allows one to acknowledge the value of liberal institutions while at the same time recognizing the break between liberalism and socialism. I have attempted to show that there are significant limitations to the strategy of asserting bourgeois legal rights in the courts. In fact, Buroway argues that many overestimate the potential for liberal discourse both as a tool and a force in its own right for social transformation. He states that " [t]he extent to which liberal discourse is indeed universal and can be mobilized by any group signifies its weakness as much as its strength." 69 Certainly this is true of some of the mobilization and litigation strategies adopted to date which involve the Canadian Charter of Rights and Freedoms. Groups with opposing political agendas have evoked the same rights for incompatible purposes. But an even more important limitation is the way in which the assertion of bourgeois legal rights in the courts obscures the material and social conditions which ground the struggle for social transformation. The distinction between the public and the private is maintained despite all of its obvious contradictions. 70 In order to succeed, civil rights litigation tactics must extricate gender and racial oppression from class relations. In this way, bourgeois legal rights "tend to individuate and abstract struggles from their material and social basis."71

Does this mean that the assertion of bourgeois legal rights in the courts should be avoided as part of the struggle for social transformation? Simply because the extension of liberal rights does not bring about the end of capitalism it does not follow that these rights are not important features of a democratic society. In the face of legislative, executive, administrative and police incursion, it is important to assert and defend bourgeois legal rights. But it is difficult to see how these rights give us much guidance about how to establish and maintain democratic processes which transcend the distinction between the public and private spheres. The democracy we have now, however important a shield against the abusive exercise of power, is part of a system which accepts vast disparities in power. It may be important to assert bourgeois legal rights as part of a short-term defense against retrenchment, but this is very different from asserting that such legal rights are an essential aspect of the struggle for social transformation.

\section{Notes}

* I would like to thank Harry Glasbeek, Eric Tucker, Henning Von Bauer and two anonymous reviewers of the Canadian Journal of Law and Society for their helpful comments. All errors are my own.

1. Charter of Rights and Freedoms, Part I of the Constitution Act, 1982 [enacted by the Canada Act, 1982 (U.K.), Ch. Il, Sched. B], ss. 1-34. 


\section{What Do We Mean by Law and Social Transformation/Fudge}

2. See the renewed call for entrenching a Bill of Rights in Britain which is being orchestrated by a coalition of left-leaning individuals, "Charter 88," New Statesman 2 (1988), 4-12.

3. Since a large part of my critique of theoretical writing on the transformative capacity of law concerns its failure to be precise about what aspect of law is being discussed, I want to specify what I do not mean by liberal legal rights. I do not mean social and redistributional entitlements (such as workers compensation, medical and educational services, occupational health and safety protection and affirmative action programs, to name a few) which are embodied in legislation. While such social entitlements take a legal form, they can be distinguished from liberal legal democratic rights. Liberal legal rights are, by contrast, captured by the rule of law and civil rights-equal treatment under the law, freedom of association, expression and religion. Moreover, they are achieved through litigation in the common law courts. It is these liberal legal (bourgeois) rights which are distinguishing features of liberal democracies.

4. S. Brickey and E. Comack, "The Role of Law in Social Transformation: Is a Jurisprudence of Insurgency Possible?" Canadian Journal of Law and Society 2(1987), 97; and A. Bartholemew and S. Boyd, "The Political Economy of Law," in Wallace Clement and Glen Williams (eds.), The New Canadian Political Economy (Kingston: McGillQueen's University Press, 1989), 212. Although the two articles employ different methodologies, they are, however, very similar in terms of analysis and prescription.

5. Brickey and Comack, "The Role of Law in Social Transformation," 102.

6. Bartholemew and Boyd, "The Political Economy of Law," 233.

7. According to Brickey and Comack, "The Role of Law in Social Transformation," 103, "the question remains, then as to what direction theoretical reformulation should proceed in order to fashion an approach which incorporates, rather than abandons, law as a potential agent for social transformation." Moreover, Bartholemew and Boyd, "The Political Economy of Law," 213, "insist that a political economy of law must attempt to theorize and capture both the limitations that law and legal institutions present for progressive movements and class struggles within capitalist societies and the potentialities of law and rights for class struggles and progressive forces within and beyond capitalism." My main point of disagreement with this important new work is with the related claims that law can be an agent for social transformation and that law contains the seeds of its own resistance. These claims, I argue, lack precision in what is meant by law.

8. Brickey and Comack, "The Role of Law in Social Transformation," 103.

9. Colin Sumner, "The Rule of Law and Civil Rights in Contemporary Marxist Theory," Kapitalistate 9 (1981), 63 at 85.

10. Ibid., 89. 
11. Brickey and Comack, "The Role of Law in Social Transformation," 103; Bartholemew and Boyd, "The Political Economy of Law," 231-232.

12. Ellen Meiksins Wood, The Retreat from Class (London: Verso, 1986), 163.

13. Leo Panitch and Donald Swartz, The Assault on Trade Union Freedoms (Toronto: Garamond Press, 1988).

14. In Quebec v. Brunet [1990] S.C.J. No. 13 the Supreme Court of Canada upheld a decision of the Quebec Court of Appeal striking down a 1983 statute which prevented provincial government employees from striking. Although the law itself was published in both languages, the collective agreements to which the law referred were published in French only. The Quebec Court of Appeal ruled that the collective agreement documents were part of the legislation and that their publication in French only rendered the legislation unconstitutional. While this may be considered a Charter victory for organized labour, it is a peculiar form of victory. A Quebec union is arguing that legislation which prohibits striking is invalid because the collective agreements which are being extended by the legislation are only in one of the two official languages-French.

15. Panitch and Swartz, The Assault on Trade Union Freedoms.

16. Michael Mandel, The Charter of Rights and the Legalization of Politics in Canada (Toronto: Wall and Thompson, 1989); Harry J. Glasbeek and Michael Mandel, "The Legalization of Politics in Advanced Capitalism: The Canadian Charter of Rights and Freedoms," Socialist Studies 2 (1984) 84.

17. Reference Re Public Service Employee Relations Act (1987), [1987] 1 S.C.R. 313 at 390 (hereinafter referred to as Alberta Reference); Public Service Alliance of Canada $v$. A.G. of Canada (1987), [1987] I S.C.R. 424; Retail, Wholesale and Department Store Union, Local 544 v. Gov't of Sask. (1987), [1987] S.C.R. 460. For a more thorough discussion of these cases see Judy Fudge, "Labour, The New Constitution and Old Style Liberalism," in Labour Law Under the Charter (Kingston: Queen's Law Joumal and Industrial Relations Centre, 1988), 61-111.

18. Alberta Reference, ibid. at 409. Dickson and Wilson found that the freedom of association included the right to strike, but they disagreed as to whether the impugned statutes in the right to strike triology were saved by s. 1. See Fudge, "Labour, The New Constitution and Old Style Liberalism."

19. Retail, Wholesale and Department Store Union, Local 580 v. Dolphin Delivery Ltd., [1986] 2 S.C.R. 573.

20. Ibid., 600 .

21. The Supreme Court of Canada issued two decisions on October 20, 1988, dealing with the legality of picketing courthouses. The British Columbia case provided the 
reasoning for the Newfoundland case: British Columbia Government Employees' Union v. A.G. of B.C. (1988), 88 C.L.L.C. 14,047; Newfoundland Association of Public Employees v. A.G. of Newfoundland (1988), 88 C.L.L.C. 14, 046.

22. British Columbia Government Employees' Union v. A.G. of B.C. (1988), 88 C.L.L.C. 14,047 at 12,251 .

23. Ibid., 12,255 .

24. Ibid., 12,263 .

25. Harry S. Glasbeek, "Some Strategies for an Unlikely Task: The Progressive Use of Law," University of Ottawa Law Review, forthcoming.

26. Eric Tucker, Administering Workplace Danger (Toronto: University of Toronto Press, forthcoming).

27. Eric Tucker, "The Law of Employers' Liability in Ontario 1861-1900: The Search for a Theory," Osgoode Hall Law Journal 22 (1984), 213-80.

28. Judy Fudge, "The Public/Private Distinction: The Possibilities of and the Limits to the use of Charter Litigation To Further Feminist Struggles," Osgoode Hall Law Journal 25 (1987), 485-554; Rosemary Warskett, "Bank Worker Unionization and the Law," Studies in Political Economy 25 (1988), 41-73.

29. For a discussion of the courts' willingness to strike down remedial legislation designed to aid workers during the depression of the 1930s, see W.C. McConnell, "Some Comparisons of the Roosevelt and Bennett 'New Deals'," Osgoode Hall Law Journal 9 (1971), 221.

30. See Glasbeek, "Some Strategies for an Unlikely Task," 103, where he discusses the challenges launched against welfare rights, workers' compensation legislation, union dues checkoffs and union constitutions designed to protect a women's teachers' union from raiding by the rival men's teachers' union. Few of these challenges have been successful, but the point is that it is extremely unlikely the political compromise would have been challenged if not for the Charter.

31. Isabella Bakker, "The Political Economy of Gender," in Wallace Clement and Glen Williams (eds.), The New Canadian Political Economy (Kingston: McGill-Queen's University Press, 1989), 99-115; Heather Jon Maroney and Meg Luxton, "From Feminism and Political Economy to Feminist Political Economy" in Heather Jon Maroney and Meg Luxton (eds.), Feminism and Political Economy: Women's Work, Women's Struggles (Toronto: Methuen, 1987) 5-28.

32. Z.R. Eisenstein, Feminism and Sexual Equality: Crisis in Liberal America (New York: Monthly Review, 1984), 12. 
33. S.A.M. Gavigan, "Women and Abortion in Canada: What's Law Got to Do With It?" in Maroney and Luxton (eds.), Feminism and Political Economy, 263 at 271.

34. R. v. Morgentaler (1988), [1988] 1 S.C.R. 30, 82 N.R. 1 (S.C.C.).

35. Criminal Code, R.S.C. 1970, c. C-34, s. 251.

36. Shelley Gavigan, "Morgentaler in Perspective: The Historical Background to the 1988 Decision of the Supreme Court of Canada," paper prepared for Constitutional Politics and the Future: The Repeal of Canada's Abortion Law in Comparative Perspective, Centre for Intemational Affairs, Harvard University, May 1988.

37. Ibid., 15; See also Patricia Antonyshyn, B. Lee and Alex Merrill, "Marching for Women's Lives: The Campaign for Free-Standing Abortion Clinics in Ontario" in Frank Cunningham et al (eds.), Social Movements and Social Change, Socialist Studies 4 (1988), 129-156.

38. Women's Legal Education and Action Fund, (1988) 5 LEAF LETTER at 4.

39. Fudge, "The Public/Private Distinction," 542.

40. Bill C-41, An Act Respecting Abortion, H.E. 2nd Sess. 134 Part, 1989.

41. See the most recent challenge to Roe v. Wade, Webster v. Reproductive Health Services No. 88-605, U.S. Sup. Ct. A transcript of the oral arguments is reproduced in The New York Times, 27 April 1989, K14-16. See also Rosalind Pollack Petchesky, Abortion and Women's Choice (London: Verso, 1986), 286-325, for an account of the Roe v. Wade backlash.

42. Glasbeek, "Some Strategies for an Unlikely Task"; Rueben A. Hasson, "The Charter and Social Legislation," Paper presented at the Conference on the Canadian Charter of Rights and Freedoms, Edinburgh May 21, 1988. However in Schacter v. Canada, [1990] F.C.J. No. 127 the Federal Court of Appeal stated that under-inclusive legislation invites a remedy-extending benefit, even if the extension of benefits requires an appropriation of public funds. However, the Court noted that it is open to the legislature to amend the law to deny benefits equally despite the fact that the court had extended the benefits.

43. Pay equity legislation, maternity benefits, state subsidized daycare are just a few examples of the type of redistributive legislation and government policies required by women to overcome burdens imposed by the private sphere of the labour market and family.

44. Judy Fudge, "The Effect of Entrenching a Bill of Rights upon Political Discourse: Feminist Demands and Sexual Violence in Canada," International Journal of the Sociology of Law 17 (1989), 445. 
45. Eric Hobsbawn, Workers: Worlds of Labour (New York: Pantheon Books, 1984), 310.

46. Glasbeek and Mandel, "The Legalization of Politics in Advanced Capitalism"; Mandel, The Charter of Rights and the Legalization of Politics in Canada.

47. Mandel, The Charter of Rights and the Legalization of Politics in Canada, 61-71.

48. Fudge, "The Effect of Entrenching a Bill of Rights upon Political Discourse."

49. Ibid.

50. Andrews v. Law Society of British Columbia, [1989] 1 S.C.R. 43.

51. Fudge, "The Effect of Entrenching a Bill of Rights upon Political Discourse."

52. L.E.A.F. Factum in Canadian Newspapers Co. v. A.G. Canada, October, 1987.

53. Mandel, The Charter of Rights and the Legalization of Politics in Canada, 310.

54. According to MacIntyre in Andrews, section 15(1) of the Charter provides for every individual a guarantee of equality before and under the law, as well as the equal protection and equal benefit to the law without discrimination. This is not a general guarantee of equality; it does not provide for equality between individuals or groups within society in a general or abstract sense, nor does it impose on individuals or groups an obligation to accord equal treatment to others. It is concerned with the application of the law.

55. Constitutional arguments about natural justice and formal equality have spilled into the legislative discussions of sexual assault policy. The federal government introduced a series of amendments to the Criminal Code which were specifically designed to bring the impugned provisions in line with the Charter. Throughout the parliamentary proceedings the Minister of Justice asserted that although the government preferred the amendments suggested by the women's organizations it "did not want to offend any provision of the Charter" (Canada, 1986-87, 1:40). In the end the constitutional arguments won out and legislation which was specifically designed to accommodate what the judiciary regarded as the imperatives of the constitution was proclaimed; See Fudge, "The Effect of Entrenching a Bill of Rights upon Political Discourse."

56. Lise Gotell, "The Canadian Women's Movement, Equality Rights and the Charter," Canadian Research Institute for the Advancement of Women, forthcoming; Fudge, "The Effect of Entrenching a Bill of Rights upon Political Discourse."

57. Glasbeek, "Some Strategies for an Unlikely Task."

58. Canadian examples include Mandel, The Charter of Rights and the Legalization of 
Politics in Canada; Glasbeek, "Some Strategies for an Unlikely Task"; Hasson, "The Charter and Social Legislation"; and Andrew Petter, "Immaculate Deception: The Charter's Hidden Agenda," The Advocate 45 (1987), 857.

59. Kimberle Williams Crenshaw, "Race, Reform, and Retrenchment: Transformation and Legitimation in Antidiscrimination Law," Harvard Law Review 101 (1988), 13311397; M.M. Matsuda, "Looking to the Bottom: Critical Legal Studies and Reparations," Harvard Civil Rights and Civil Law Review 22 (1987), 323; P.A. Williams, "Taking Rights Aggressively: The Perils and Promise of Critical Legal Theory for Peoples of Colour," Law and Inequality 5 (1987), 103.

60. Crenshaw, "Race, Reform, and Retrenchment," 1377.

61. Brown v. Board of Education, 347 U.S. 483 (1954).

62. Crenshaw, "Race, Reform and Retrenchment," 1378.

63. See the citations provided by Crenshaw, in "Race, Reform and Retrenchment," at note 3; See also Isabel Wilkerson, "Two Decades of Decline Chronicled by Kerner Follow-up Report," The New York Times, March 2, 1988, A12.

64. Richard Gambitta, "Litigation, Judicial Defence and Policy Change," in Richard Gambitta et al. (eds.), Governing through the Courts (Beverly Hills: Sage Publications, 1981), 261; quoted in Mandel, The Charter of Rights and the Legalization of Politics in Canada, 51.

65. Crenshaw, "Race, Reform and Retrenchment," 1382-1383.

66. See William Bradford Reynolds, "The Reagan Administration's Civil Rights Policy: The Challenge for the Future," Vanderbilt Law Review 42 (1989), 993-1101; and Drew S. Days, III, "The Courts' Response to the Reagan Civil Rights Agenda," Vanderbilt Law Review 42 (1989), 1003-1016, for a discussion of the Reagan administration's litigation strategy to roll back racial affirmative action policies and the courts' response. In Patterson v. McLean Credit Union, No. 87-107, a case pending before the U.S. Supreme Court, the court decided to reconsider the rights of minorities to sue private parties for racial discrimination under a Post-Civil War Statute. See Runyon v. McCeary, 96 S Ct. 2586 (1976).

67. The [Toronto] Globe and Mail, 21 June, 1989, A8.

68. Ellen Meiksins Wood, "Capitalism and Human Emancipation," New Left Review (1988) 3-20, at 8.

69. Michael Buroway, "Should We Give Up on Socialism?" Socialist Review 19 (1989), 57-74, at 60 .

70. Here it is important once again to refer to the Supreme Court's decisions in Dolphin 
What Do We Mean by Law and Social Transformation/Fudge

Delivery, [1986] 2 S.C.R. 573 and Andrews v. Law Society of B.C., [1989] 1 S.C.R. 143 which were discussed earlier.

71. Bartholemew and Boyd, "The Political Economy of Law," 229. The only problem with their proposition in its original form is that it is overly general. Bartholemew and Boyd should be more careful to specify what they mean when they refer to law 
CJLS/RCDS Vol. 5 (1990) 